\title{
31. SEDIMENTARY SEQUENCES AT DEEP SEA DRILLING PROJECT SITE 464: SILICIFICATION PROCESSES AND TRANSITION BETWEEN SILICEOUS BIOGENIC OOZES AND BROWN CLAYS ${ }^{1}$
}

\author{
Anne-Marie Karpoff, Michel Hoffert, and Norbert Clauer, Centre de Sédimentologie et \\ Géochimie de la Surface, (C.N.R.S.), Strasbourg, France
}

\begin{abstract}
The relationships between mineralogical and geochemical data on the three successive sedimentary facies at Deep Sea Drilling Project Site 464 are studied. The evolution of siliceous biogenic sediments is derived from the analyses of one Fe-Ti smectite concretion, and of siliceous aggregates occurring in the pelagic "brown clays." Along the sedimentary section, the trace elements enriching the authigenic silicates and the Fe-Mn oxyhydroxides vary, depending on the marine environment. The proportion of clays and carbonates into the siliceous deposits controls the diagenetic evolution of silica making up the quartz aggregates from the "brown clay" or the cristobalite cherts.
\end{abstract}

\section{INTRODUCTION}

Site 464 is on the northern flank of Hess Rise, northwest Pacific, in a water depth of 4637 meters (Fig. 1). According to shipboard lithological studies, the composite sequence overlying the basement comprises three main units (Fig. 2). From bottom to top, the lowest unit (Unit 3, 219-m thick) contains cherts, limestones, and chalk of Albian to Cenomanian age. Unit 2 (53-m thick), of soft brown clays and pelagic oozes, is of Early Cretaceous to late Miocene age, according to Doyle and Riedel (this volume). The youngest unit (Units $1 \mathrm{~A}$ and $1 \mathrm{~B}, 33 \mathrm{~m}$ ) consists of clays, siliceous biogenic muds, and oozes of late Miocene to Pleistocene age.

\section{SEDIMENTOLOGY AND MINERALOGY}

\section{METHODS}

The sediment lithology was defined on the basis of smear-slide observations (Fig. 3 and Table 1).

The mineralogical composition of the sediments was determined by X-ray-diffraction techniques. The X-ray-diffraction charts from non-oriented powders were obtained using bulk material or coarse fraction, under the following conditions: $\mathrm{CuK} \alpha$ radiation, Ni filter, 98 $\mathrm{kV} / 18 \mathrm{~mA}, 0.1$ to $1^{\circ}$ slits, $1 \% \mathrm{~min}$ speed. The identification of clay minerals in the $<2-\mu \mathrm{m}$ fractions was made on three types of oriented aggregates: untreated, ethylene-glycol-treated, and heated, according to the methods of the Institut de Géologie in Strasbourg (Mise au point collective, 1975).

Some clay fractions were also studied by micro-diffraction on isolated particles, by transmission electron microscope (TEM: Phillips EM 300), using the method of Trauth et al. (1977).

\section{RESULTS}

Descriptive data are given in Table 1. The composition of these lithologic units is as follows:

Unit IA: 3.5-19.0 meters (Samples 464-2-3, 1-3 cm; 464-2-3, 50-52 cm; and 464-3-4, 145-146 cm)

This unit is made up of siliceous nannofossil ooze, which passes gradually to a muddy siliceous ooze and

\footnotetext{
1 Initial Reports of the Deep Sea Drilling Project, Volume 62.
}

clayey radiolarian ooze. The prevalent minerals are calcite and amorphous silica or opal from pelagic biogenic components such as coccoliths, discoasters, foraminifers, radiolarians, and diatoms. Quartz, feldspars, and volcaniclastic fragments occur. Clays, as illite and smectites, usually form small aggregates within and around the siliceous organisms. Small amounts of zeolites and barite occur at the bottom of the sedimentary sequence, whereas the siliceous organisms are poorly preserved and more dissolved. In these deposits, a lightyellowish-brown $(2.5 \mathrm{Y} 6 / 4)$ concretion was found, the shape and surface of which are irregular (Fig. 4). Its concentric and colloform structure is similar to that of metalliferous nodules described by Sorem and Fewkes (1977). The mineralogical analyses establish that it is made of smectites with some quartz. Very scarce manganiferous oxides as small patches between the successive clay layers are observable. Detailed geochemical and microprobe studies were made on this clayey concretion.

Unit IB: 19.0-36.5 meters (Samples 464-3-5, 5-6 cm; 464-5-3, 4-6 cm; and 464-5-3, 140-142 cm)

Unit IB comprises in the upper part a muddy siliceous ooze, a gradual transition from Unit IA, and in the lower part siliceous clays. Similar to the sediments of the lower section of Unit IA, Unit IB muds are made of amorphous silica (biogenic opal), quartz, trace amounts of plagiocase, barite, and phillipsite. The clay-minerals content increases and comprises illite, smectites, scarce kaolinite, and mixed-layer clays. Toward the bottom of this sequence, ferromanganese oxides and micronodules become more abundant and volcanic glasses occur. On the X-ray charts from slides of untreated and oriented clay fractions, the main peak of smectites is at 13 to $14 \AA$. The SEM study shows that the smectites are strongly coupled to abundant siliceous-organism fragments, particularly diatoms. The smectite particles are "ringlet"'-shaped and exhibit irregular outlines. They are related to authigenic clay minerals described by Hoffert (1980) in Panama Basin. 


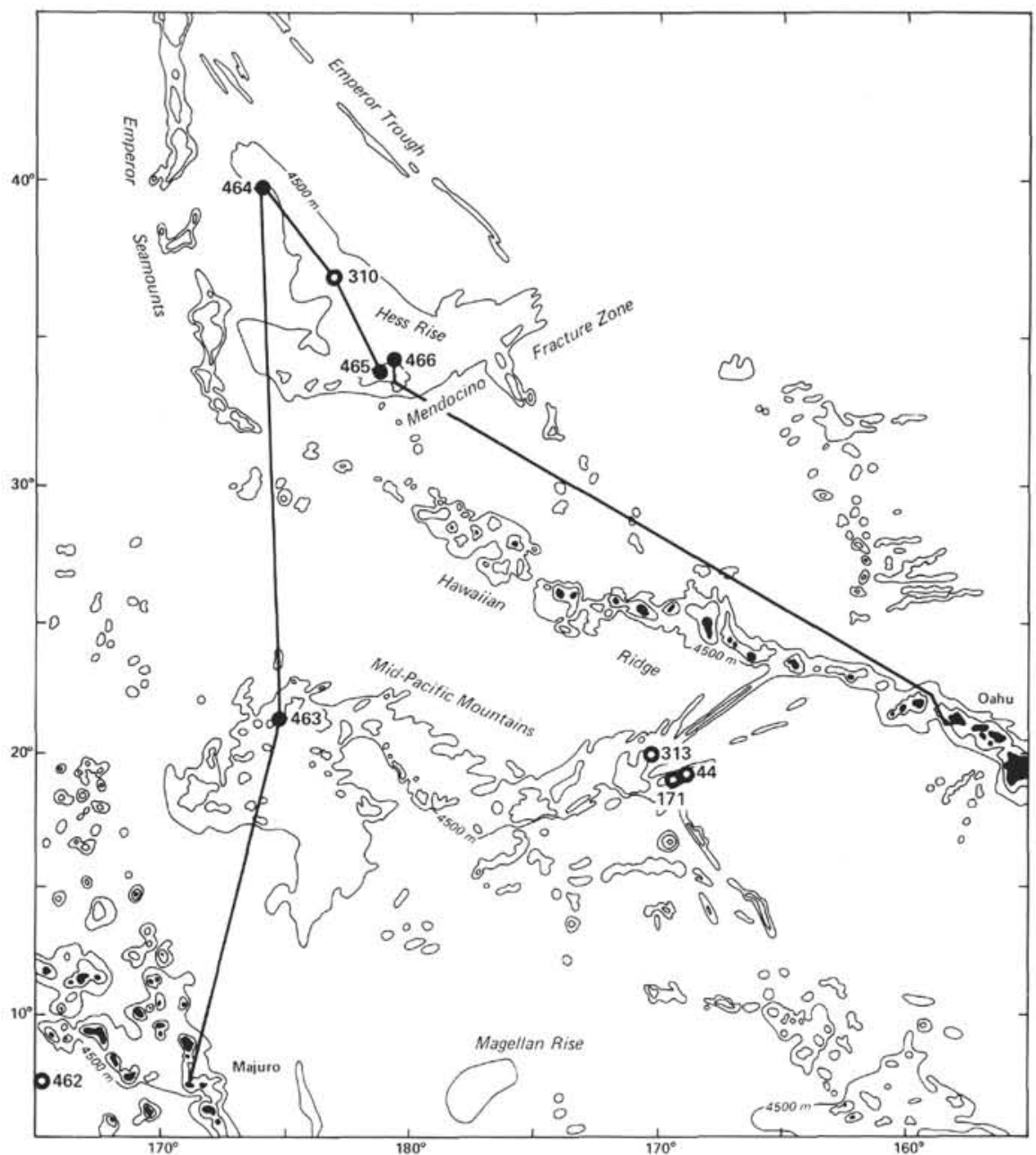

Figure 1. Location of Site 464 and nearest previous sites. Isobaths 4500 and 3500 meters.

Unit II: 36.5-89.0 meters (Samples 464-7-5, $80-82 \mathrm{~cm}$; and $464-10-4,70-72 \mathrm{~cm}$ )

Unit II belongs to the "red clays" or pelagic "brown clay" facies. The sediment is made up of $95 \%$ clays, $5 \%$ $\mathrm{Fe}-\mathrm{Mn}$ oxyhydroxides, with trace amounts of radiolarians, coccoliths, volcaniclastic particles, and glasses. Microcline, quartz, and phillipsite were also identified by X-ray-diffraction analysis on non-oriented powders of bulk sediment. The two available and analyzed samples are located at the upper part of the unit (first sample), and at the bottom, near the limit with underlying Unit 3 (second sample). Similar in bulk mineralogical composition, the two samples differ from each other by their age (Plio-Miocene and Cretaceous, respectively), and also by the composition and nature of coarse $(<63-\mu \mathrm{m})$ and clay $(<2-\mu \mathrm{m})$ fractions.

The SEM and TEM investigations were made on the bulk sediment, on the coarse and clay fractions.

\section{Upper Deposits of Unit II}

The upper part of the sequence contains phillipsite, which occurs on sponge spicules and appears to be related to this particular restricted environment (Plate 1,
Figs. 1 and 2). In the clayey matrix of the sediment, manganiferous micronodules are observed, growing into cavities or pores, probably from residual dissolved siliceous organisms (Plate 1, Figs. 3 and 4). Smectites prevail in the clay fraction; on X-ray charts, they have a main peak at $15 \AA$. Very scarce palygorskite is associated. In TEM photomicrographs, the smectite particles show very diffuse and fibrous outlines, as laths (Plate 1, Figs. 5 and 6), and differ from those of overlying Unit II. They are similar to those formed from dissolved radiolarian silica, described by Hoffert (1980).

\section{Lower Part of Unit II}

The coarse fraction of the Cretaceous brown clay comprises numerous white slabs, microconcretions, aggregates, and particles. These fragments are made of quartz with low contents of cristobalite (opal-CT). SEM observations show that these microconcretions are silicified coccoliths (Plate 2, Fig. 1) or radiolarians, with some zeolite crystals among the siliceous "lepispheres" (Plate 2, Figs. 2, 3, 4). The zeolite occurrence was defined by spectrochemical micro-diffraction (Tracor system). The clay fraction of Cretaceous brown sediments contains prevalent smectites (15 $\AA$ ), scarce palygor- 
SITE 464

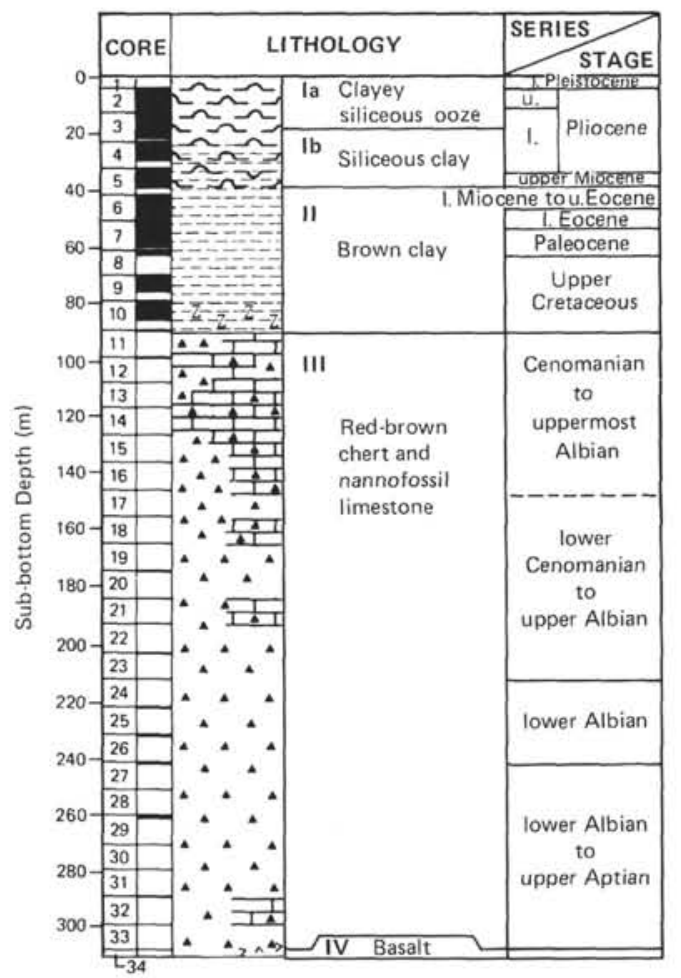

Figure 2. Lithologic core description of sedimentary units of Site 464 .

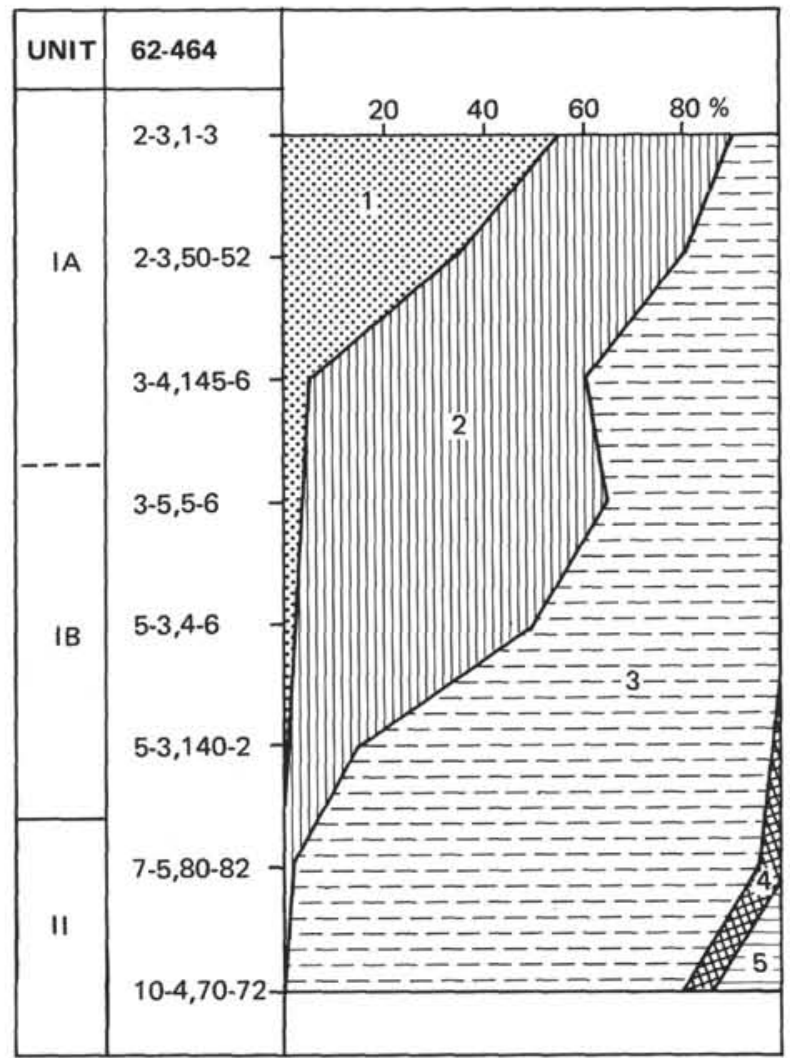

Figure 3. Composition of soft sedimentary Units I and II at Site 464, established by smear-slide data. 1. Calcareous organisms (nannofossils and foraminifers). 2. Siliceous organisms (radiolarians, diatoms, and sponge spicules). 3. Clays. 4. Micronodules and $\mathrm{Fe}-\mathrm{Mn}$ oxides. 5. Volcanic glass and volcaniclastic minerals, skite, and also traces of detrital clays, as illite and chlorite. The SEM investigations show the occurrence of palygorskite laths with the bigger smectite particles and scarce small siliceous globules (Plate 2, Figs. 5 and 6).

\section{Unit III: 89.0-307.5 meters (Samples 464-13,CC;} 464-26-1, 82-84 cm; and 464-26-1, 88-90 cm)

The thick Unit III comprises brown-red cherts, silicified chalk, and limestones, of late Albian to Cenomanian. It overlies the basalts of Unit IV. Cherts are made of prevalent cristobalite (opal-CT), associated with quartz and sometimes calcite. Traces of radiolarians are visible in thin sections.

In summary, the mineralogical variations of the sedimentary sequence at Site 464 illustrate a gradual transition from essentially siliceous biogenic oozes to the brown clay facies, which lies on cherts. Successive and different mineral assemblages correspond to each unit of the sequence, with a progressive change of the proportion of the calcareous or siliceous biogenic phases, and of the detrital or authigenic minerals (Fig. 3).

From top to bottom in Unit I, the calcareous biogenic phases decrease when the siliceous organisms increase. In the lower part of this lithologic unit, siliceous organisms are poorly preserved and dissolved, and the content of biogenic phases decreases, with a correlative increase in clay content. The pelagic biogenic oozes range downward to clayey sediments. On top (Unit IA), the clay fraction essentially is composed of detrital minerals, and the scarce authigenic minerals comprise barite, related to the dissolution of organisms, and zeolite. Clayey and quartz nodules occur in the soft deposits. At the base (IB), clays are prevalent and are essentially authigenic "ringlet"-shaped smectites; metalliferous oxyhydroxides appear.

The pelagic clays of Unit II are characterized by the abundance of authigenic smectites, with fibrous outlines, and by the occurrence of palygorskite. Siliceous microconcretions, as quartz and opal-CT, occur in the lower part of the soft sediments overlying the cherts.

\section{GEOCHEMISTRY}

\section{METHODS}

The geochemical data refer to the same set of studied samples. Major- and trace-element analyses were performed following the method described by Besnus and Lucas (1968) and Besnus and Rouault (1973), using arc spectrometry and an ARL quantometer. The method consists of melting the sample in a mixture of lithium tetraborate and introducing the melt into a glycolated solvent. Trace elements were determined using graphite disks, as described by Besnus and Lucas (1968). $\mathrm{Na}$ and $\mathrm{K}$ were determined by emission spectrometry. Relative precision is $\pm 2 \%$ for major elements, and $\pm 20 \%$ for trace elements.

\section{Results}

Bulk-chemistry data are presented in Tables 2 and 3 for major and trace elements. The prevalent-component variations along the sequence are shown in Figure 5.

The variation of the major elements and of the trace elements supplement the mineralogical data and define the evolution of the sedimentary components. Selective microprobe investigations detailed the chemical relationships between some mineral phases. 
Table 1. Results of smear-slide investigations and X-ray-diffraction analyses of sedimentary deposits from Site 464.

\begin{tabular}{|c|c|c|c|c|c|}
\hline $\begin{array}{c}\text { Sample } \\
\text { (interval in } \mathrm{cm} \text { ) }\end{array}$ & $\begin{array}{l}\text { Lithologic } \\
\text { Unit }\end{array}$ & Sediments & Smear-Slide Components & $\begin{array}{l}\text { Mineralogy of } \\
\text { Bulk Sediment }\end{array}$ & $\begin{array}{l}\text { Mineralogy of } \\
\text { Clay Fraction }\end{array}$ \\
\hline $464-2-3,1-3$ & & $\begin{array}{l}\text { Radiolarian-nannofossil } \\
\text { ooze }\end{array}$ & $\begin{array}{l}\text { Coccoliths, discoasters, and fragmented } \\
\text { foraminifers; radiolarians and diatoms, } \\
\text { scarce silicoflagellates, clays as reddish } \\
\text { aggregates in or around the siliceous } \\
\text { organisms, quartz }\end{array}$ & $\begin{array}{l}\text { Calcite, quartz, clays } \\
\text { (illite and smectite) } \\
\text { feldspars }\end{array}$ & \\
\hline $464-2-3,50-52$ & Unit IA & $\begin{array}{l}\text { Clayey radiolarian- } \\
\text { nannofossil ooze }\end{array}$ & $\begin{array}{l}\text { Diatoms and radiolarians, coccoliths and } \\
\text { discoasters, clays in organisms, scarce } \\
\text { quartz and volcaniclastic particles, } \\
\text { feldspars }\end{array}$ & $\begin{array}{l}\text { Calcite, quartz, } \\
\text { amorphous silica, } \\
\text { clays (illite and } \\
\text { smectite) feldspars }\end{array}$ & \\
\hline $464-2-3,145-146$ & & $\begin{array}{l}\text { Radiolarian ooze with } \\
\text { clays and authigenic } \\
\text { phases }\end{array}$ & $\begin{array}{l}\text { Radiolarians and diatoms, poorly pre- } \\
\text { served, clays and globules of Fe- } \\
\text { oxyhydroxides, coccoliths and } \\
\text { unspecified carbonates, quartz, scarce } \\
\text { volcaniclastic particles and pyroxenes }\end{array}$ & $\begin{array}{l}\text { Quartz and amor- } \\
\text { phous silica, clays } \\
\text { (illite and smectite), } \\
\text { calcite, phillips- } \\
\text { ite(?), barite, } \\
\text { feldspars }\end{array}$ & \\
\hline $464-3-5,5-6$ & & $\begin{array}{l}\text { Siliceous clay with } \\
\text { authigenic and } \\
\text { volcaniclastic } \\
\text { particles }\end{array}$ & $\begin{array}{l}\text { Radiolarians, poorly preserved, well- } \\
\text { preserved diatoms, fragmented } \\
\text { coccoliths and unspecified carbonates, } \\
\text { quartz, volcaniclastic particles }\end{array}$ & $\begin{array}{l}\text { Quartz and amor- } \\
\text { phous silica, clays, } \\
\text { plagioclases, barite, } \\
\text { phillipsite (traces) }\end{array}$ & $\begin{array}{l}\text { Illite, smectite } \\
(14 \AA), \\
\text { kaolinite, } \\
\text { interstratified } \\
\text { minerals }\end{array}$ \\
\hline $464-5-3,4-6$ & Unit IB & $\begin{array}{l}\text { Siliceous clay with } \\
\text { authigenic and } \\
\text { volcaniclastic } \\
\text { components }\end{array}$ & $\begin{array}{l}\text { Radiolarians, fragmented, clays and } \\
\text { reddish aggregates of oxyhydroxides, } \\
\text { quartz (some coarse grains), scarce } \\
\text { black micronodules, volcaniclastic } \\
\text { particles }\end{array}$ & $\begin{array}{l}\text { Clays, quartz and } \\
\text { amorphous silica, } \\
\text { phillipsite, barite, } \\
\text { plagioclases, Mn- } \\
\text { Fe oxides (traces), } \\
\text { volcanic glass }\end{array}$ & $\begin{array}{l}\text { Illite smectites } \\
\text { (13-14A), } \\
\text { interstratified } \\
\text { minerals, } \\
\text { kaolinite }\end{array}$ \\
\hline $464-5-3,140-142$ & & $\begin{array}{l}\text { Siliceous clay with } \\
\text { authigenic } \\
\text { components }\end{array}$ & $\begin{array}{l}\text { As above: clays and brownish globules of } \\
\text { of oxyhydroxides, poorly preserved } \\
\text { siliceous organisms (radiolarians and } \\
\text { diatoms), volcanic particles and glass, } \\
\text { coarse grains of quartz }\end{array}$ & $\begin{array}{l}\text { Quartz, clays, amor- } \\
\text { phous silica and } \\
\text { volcanic glass, } \\
\text { phillipsite, barite, } \\
\text { Mn-Fe oxides }\end{array}$ & $\begin{array}{l}\text { Illite smectites } \\
(13-14 \AA), \\
\text { chlorite, } \\
\text { interstratified } \\
\text { minerals }\end{array}$ \\
\hline $464-7-5,80-82$ & & $\begin{array}{l}\text { Brown clay (pelagic } \\
\text { clay) }\end{array}$ & $\begin{array}{l}\text { Brownish globules, very abundant, } \\
\text { sometimes in residual organisms, } \\
\text { clays, micronodules, radiolarians, } \\
\text { scarce fragments of sponge spicules, } \\
\text { few coccoliths, volcaniclastic particles }\end{array}$ & $\begin{array}{l}\text { Clays, microline, } \\
\text { calcite, quartz, } \\
\text { phillipsite, Mn-Fe } \\
\text { oxides (traces) }\end{array}$ & $\begin{array}{c}\text { Smectites }(15 \AA), \\
\text { palygorskite } \\
\text { (scarce) }\end{array}$ \\
\hline $464-10-4,70-72$ & Unit II & $\begin{array}{l}\text { Brown clay, pelagic } \\
\text { clays with coarse } \\
\text { white slabs }\end{array}$ & $\begin{array}{l}\text { Clays and diffused oxyhydroxides } \\
\text { homogeneous on the slide, splintered } \\
\text { fragments of glass or siliceous } \\
\text { organisms, radiolarians and sponge } \\
\text { spicules, scarce fragments of cocco- } \\
\text { liths and unspecified carbonates, } \\
\text { quartz }\end{array}$ & $\begin{array}{l}\text { Quartz, clays, silica as } \\
\text { cristobalite, Fe- } \\
\text { hydroxide } \\
\text { (goethite), calcite } \\
\text { (traces), ecolite } \\
\text { (philipsite), } \\
\text { volcanic glass, } \\
\text { feldspars (traces); } \\
\text { Coarse fraction: white } \\
\text { slabs are made of } \\
\text { quartz and scarce } \\
\text { cristobalite }\end{array}$ & $\begin{array}{l}\text { Smectite (15 } \mathrm{A}) \text {, } \\
\text { illite, chlorite } \\
\text { (traces), } \\
\text { palygorskite } \\
\text { (traces) }\end{array}$ \\
\hline $13, \mathrm{CC}$ & Unit III & $\begin{array}{l}\text { Siliceous limestone } \\
\text { and cherts }\end{array}$ & & $\begin{array}{l}\text { White zones of } \\
\text { siliceous limestone } \\
\text { are made of } \\
\text { cristobalite, calcite, } \\
\text { and quartz }\end{array}$ & \\
\hline
\end{tabular}

\section{Major-Element Variations: Signature of the Main Mineral Phases}

\section{Bulk Sediments from Units I and II}

The variation of major elements reflects the mineralogical composition, its fluctuations and evolution. In Unit I, occurrence of calcareous nannofossils is shown by $\mathrm{Ca}$ contents, that of siliceous organisms by correspondingly higher $\mathrm{SiO}_{2}$ contents and $\mathrm{Si} / \mathrm{Al}$ ratios. The gradational and simultaneous increases of $\mathrm{Al}, \mathrm{Fe}, \mathrm{Ti}$ and $\mathrm{Mg}$ contents correspond to those of clay phases in sediments of Unit I (Figs. 5 and 6); the presence of authigenic minerals such as barite, zeolite and oxyhydroxides is indicated by the $\mathrm{Ba}, \mathrm{K}$, and $\mathrm{Mn}$ contents.

From top to bottom, the deposits of Unit II are differentiated by several chemical criteria (Figs. 5 and 6). In the upper part, the proportionally higher $\mathrm{Ti}, \mathrm{Fe}$, and $\mathrm{K}$ contents are related to the occurrence of volcaniclastic particles and more-abundant zeolites. These variations are also related to the clay fraction of the sediment, which could contain more $\mathrm{Fe}$ and $\mathrm{Ti}$ than that of overlying Unit I. In the lower part, the occurrence of quartz aggregates and concretions, metalliferous oxyhydroxides, and micronodules induce, respectively, the increas- 


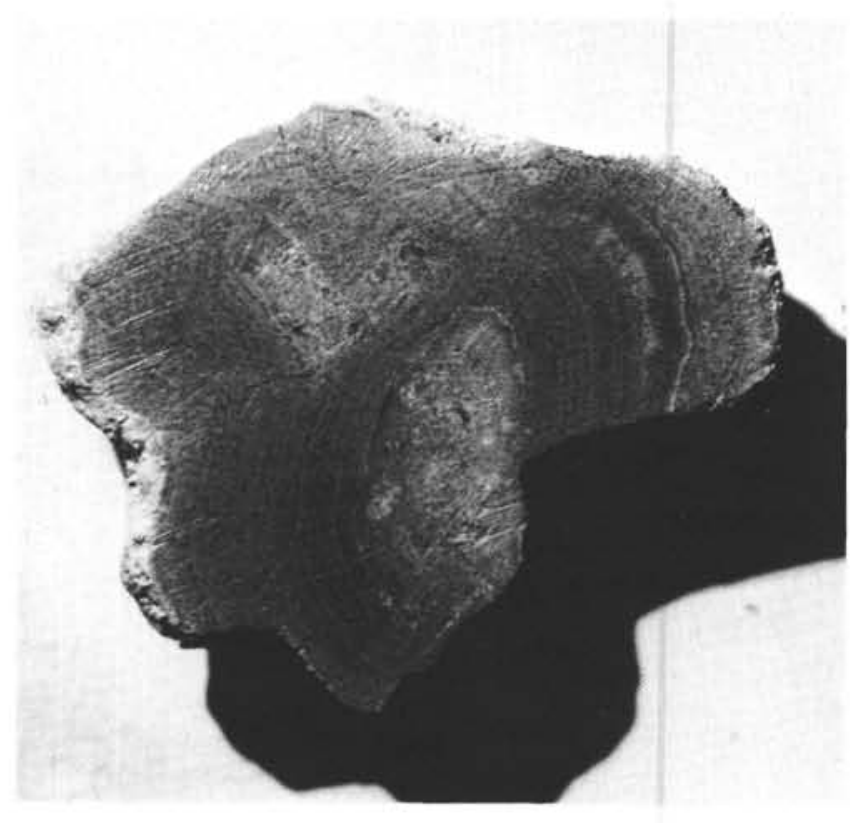

Figure 4. Photograph of a section of a clayey siliceous concretion from the deposits of Unit IA. Sample 464-2-3, 45-47 cm $(\times 1.5)$.

ing $\mathrm{Si}, \mathrm{Mn}$, and $\mathrm{Fe}$ contents, relative to $\mathrm{Al}$ and $\mathrm{Ti}$ (in clays).

\section{Clayey Nodule from Unit 1}

\section{Structural Formula}

The clayey concretion found in the Unit I deposits was also analyzed. The structural formula of the smectite forming this nodule is established using Millot's calculation (1949). The 9.4\% silica excess (assuming that no tetrahedral $\mathrm{Al}$ substitution exists in the clay) corresponds to the authigenic quartz micro-crystals interlayered between the successive clay laminae. The influence of volcaniclastic particles and feldspar fragments from the core (or nucleus) of the nodule, was considered negligible in the calculated composition of the smectite. The formula is as follows:

\author{
$\left(\mathrm{Si}_{4}\right)\left(\mathrm{Al}_{0.44} \mathrm{Mg}_{0.52} \mathrm{Fe}_{0.89} \mathrm{Ti}_{0.03}\right) \mathrm{O}_{10}(\mathrm{OH})_{2}$ \\ Interlayered cations: $\left(\mathrm{Ca}_{0.08} \mathrm{Na}_{0.049} \mathrm{~K}_{0.19}\right)$
}

The excess of octahedral cations appears to be due to the presence of $\mathrm{Mg}$ in the interlayer position. This formula is characteristic of the iron-rich beidellites and nontronites.

\section{Microscopic Investigations}

Microscopic and spectrochemical analyses were performed on the polished section of the concretion, by X-ray-dispersive energy spectroscopy (SEM Cameca 07 and Tracor system). Maps of the distribution of the prevalent elements ( $\mathrm{Si}, \mathrm{Al}, \mathrm{Ca}, \mathrm{Fe}, \mathrm{Ti}$, and $\mathrm{K}$ ) selected in a zone of the sample are given in Plate 3 . These data show the chemical composition of the concretion, and particularly of iron smectite. The successive clayey laminae are characterized by variable $\mathrm{Fe} / \mathrm{Ti}$ ratios (Plate 3 , areas $a$ and $b$ ). However, the prevalent smectite is rich in iron and titanium (a). The microprobe analyses confirm also the occurrence of (1) several zones of quartz micro-crystals, essentially located between the nodule core and the first clay lamina $(d)$, (2) small spots of $\mathrm{Fe}$-Ti oxides in the clayey matrix of the nodule core $(e),(3)$ fragments of Ca feldspars in the nodule core $(f)$, and (4) small amounts of a potassium-rich silicate, as zeolite $(c)$, and small concentrations of $\mathrm{Ca}$ as residual nannofossils $(g)$, interlayered with the successive clay deposits.

The outermost clay deposits contains small patches of manganiferous oxides which do not concentrate any iron, but are potassium- and copper-rich.

Therefore, the clays forming the indurated nodule have a different chemical composition than those of the surrounding soft sediments. The clay minerals of the siliceous ooze (Unit IA) are a mixture of detrital clays, as illite, scarce kaolinite and chlorite, and authigenic smectites which are formed on and as replacement of siliceous organisms. The chemical composition of this clay assemblage from the soft sediments appears homogeneous and constant through the sequence, and is characterized by a strong correlation of $\mathrm{Al}, \mathrm{Fe}$, and $\mathrm{Ti}$ con-

Table 2. Bulk chemical analyses of sediments from Site 464 (wt. \%).

\begin{tabular}{|c|c|c|c|c|c|c|c|c|c|c|c|c|c|c|c|}
\hline $\begin{array}{c}\text { Sample } \\
\text { (interval in } \mathrm{cm} \text { ) }\end{array}$ & $\mathrm{SiO}_{2}$ & $\mathrm{Al}_{2} \mathrm{O}_{3}$ & $\mathrm{MgO}$ & $\mathrm{CaO}$ & $\mathrm{Fe}_{2} \mathrm{O}_{3}$ & $\mathrm{Mn}_{3} \mathrm{O}_{4}$ & $\mathrm{TiO}_{2}$ & $\mathrm{BaO}$ & $\mathrm{Na}_{2} \mathrm{O}$ & $\mathrm{K}_{2} \mathrm{O}$ & $\begin{array}{c}\text { Loi } \\
\text { at } 1000^{\circ} \mathrm{C}\end{array}$ & Total & $\mathrm{Si} / \mathrm{Al}$ & $\mathrm{Mn} / \mathrm{Fe}$ & $\mathrm{CaCO}_{3}$ \\
\hline $464-2-3,1-3^{a}$ & 41.0 & 6.9 & 2.13 & 18.8 & 3.2 & 0.263 & 0.31 & 0.48 & 2.82 & 1.24 & 21.65 & 98.80 & 5.23 & 0.08 & 33.6 \\
\hline $2-3,45-47$ & 60.0 & 4.7 & 4.36 & 1.0 & 15.0 & 0.429 & 0.55 & 0.02 & 3.21 & 1.92 & 6.24 & 97.43 & 11.23 & 0.03 & 1.8 \\
\hline $2-3,50-52$ & 48.3 & 8.4 & 2.54 & 12.7 & 3.8 & 0.218 & 0.38 & 0.55 & 3.70 & 1.83 & 17.56 & 99.98 & 5.06 & 0.06 & 22.7 \\
\hline $3-4,145-146$ & 60.0 & 9.6 & 2.84 & 4.2 & 4.3 & 0.105 & 0.41 & 0.83 & 4.69 & 2.57 & 11.10 & 100.60 & 5.50 & 0.02 & 7.5 \\
\hline $3-5,5-6$ & 64.1 & 9.8 & 2.89 & 1.0 & 4.4 & 0.121 & 0.44 & 0.84 & 4.71 & 2.78 & 8.39 & 99.47 & 5.76 & 0.03 & 1.8 \\
\hline $5-3,4-6$ & 55.7 & 12.5 & 3.32 & 1.1 & 5.4 & 0.988 & 0.54 & 1.04 & 4.98 & 2.91 & 9.43 & 97.91 & 3.92 & 0.19 & 1.9 \\
\hline $5-3,140-142$ & 52.2 & 14.0 & 3.76 & 1.7 & 6.1 & 1.69 & 0.59 & 1.16 & 5.29 & 3.00 & 10.04 & 99.53 & 3.28 & 0.28 & 3.0 \\
\hline $7-5,80-82$ & 50.5 & 12.6 & 5.10 & 1.3 & 10.6 & 0.200 & 1.47 & 0.01 & 4.29 & 3.96 & 8.30 & 98.33 & 5.53 & 0.02 & 2.3 \\
\hline $10-4,70-72$ & 71.4 & 5.8 & 2.61 & 4.5 & 4.2 & 1.02 & 0.25 & 0.04 & 2.19 & 1.73 & 5.16 & 98.90 & 10.83 & 0.25 & 8.0 \\
\hline $10-4,70-72^{b}$ & 92.5 & 0.5 & 0.26 & 1.8 & 0.2 & 0.087 & 0.02 & $0.01^{\mathrm{c}}$ & 0.32 & 0.20 & 2.31 & 98.20 & 162.80 & 0.45 & 3.2 \\
\hline $13, \mathrm{CC}$ & 70.8 & 0.7 & 0.41 & 14.2 & 0.5 & 0.032 & 0.05 & 0.01 & 0.34 & 0.31 & 12.96 & 100.31 & 89.00 & 0.06 & 25.3 \\
\hline $26-1,82-84$ & 98.0 & $0.2^{\mathrm{c}}$ & $0.02^{\mathrm{C}}$ & 0.5 & 0.4 & 0.016 & $0.02^{\mathrm{C}}$ & $0.01^{\mathrm{c}}$ & 0.11 & 0.07 & 1.41 & 100.75 & 431.20 & 0.04 & 0.9 \\
\hline $26-1,88-90$ & 95.6 & $0.2^{\mathrm{c}}$ & $0.02^{\mathrm{c}}$ & 1.5 & 0.4 & $0.01^{\mathrm{c}}$ & $0.02^{\mathrm{C}}$ & $0.01^{\mathrm{c}}$ & 0.10 & 0.06 & 2.14 & 100.06 & 420.64 & 0.02 & 2.7 \\
\hline
\end{tabular}

a Contains $0.24 \% \mathrm{NiO}$ and $0.52 \% \mathrm{CuO}$.

$\mathrm{b}$ White slabs from the $>63-\mu \mathrm{m}$ fraction.

c Value below detection limit; total iron was calculated as $\mathrm{Fe}_{2} \mathrm{O}_{3}$, and total manganese as $\mathrm{Mn}_{3} \mathrm{O}_{4} ; \mathrm{CaCO}_{3}$ was calculated using the total $\mathrm{CaO}$. 
Table 3. Bulk chemical analyses of sediments from Site 464 (ppm).

\begin{tabular}{lrrrrrrrrrr}
\hline $\begin{array}{c}\text { Sample } \\
\text { (interval in cm) }\end{array}$ & \multicolumn{1}{c}{$\mathrm{Sr}$} & $\mathrm{V}$ & $\mathrm{Ni}$ & $\mathrm{Co}$ & $\mathrm{Cr}$ & $\mathrm{B}$ & $\mathrm{Zn}$ & $\mathrm{Ga}$ & $\mathrm{Cu}$ & $\mathrm{Pb}$ \\
\hline $464-2-3,1-3$ & 1032 & 55 & 126 & 25 & 51 & 107 & 102 & 14 & 44 & 259 \\
$2-3,45-47$ & 149 & 83 & $-\mathrm{c}$ & $-\mathrm{c}$ & 33 & 56 & 244 & 18 & $-\mathrm{c}^{\mathrm{c}}$ & $706^{\mathrm{d}}$ \\
$2-3,50-52$ & 758 & 39 & 139 & 36 & 63 & 118 & 109 & 19 & 69 & 289 \\
$3-4,145-146$ & 555 & 94 & 155 & 52 & 78 & 136 & 108 & 29 & 94 & 321 \\
$3-5,5-6$ & 406 & 99 & 162 & 45 & 76 & 138 & 93 & 31 & 90 & 345 \\
$5-3,4-6$ & 474 & 137 & 351 & 102 & 84 & 131 & 102 & 40 & 236 & 289 \\
$5-3,140-142$ & 547 & 144 & 430 & 158 & 87 & 149 & 130 & 37 & 289 & 452 \\
$7-5,80-82$ & 92 & 129 & 146 & 30 & 261 & 131 & 81 & 22 & 113 & 112 \\
$10-4,70-72$ & 434 & 52 & 190 & 54 & 26 & 109 & 156 & 17 & 250 & 161 \\
$10-4,70-72^{\mathrm{a}}$ & 89 & 12 & 33 & 12 & 5 b & 101 & 24 & 2 & 24 & 4 \\
$13, \mathrm{CC}$, & 289 & 10 & 8 & 3 & $5 \mathrm{~b}$ & 23 & 3 & 2 & 10 & $2^{\mathrm{b}}$ \\
$26-1,82-84$ & 31 & 29 & 10 & 13 & 8 & 65 & 12 & 6 & 27 & 12 \\
$26-1,88-90$ & 34 & 21 & 11 & 9 & 20 & 79 & 3 & 3 & 40 & 7 \\
\hline
\end{tabular}

a White slabs from $>63-\mu \mathrm{m}$ fraction.

b Value below detection limit.

c Value over the upper detection limit.

d Extrapolated value.

tents (Fig. 6), whereas the authigenic smectites of the nodule are richer in iron and titanium, with correspondingly less aluminum. The trace-element analyses also bring out the difference between the two types of clay assemblages.

\section{Variations of Trace-Element Contents:}

\section{Characterization of the Authigenic Components}

The relationships between the trace elements and associated major elements indicates the differences and evolution of the biogenic components, the detrital or primary minerals, and the authigenic phases.

\section{Strontium and Barium Contents}

In the upper radiolarian-nannofossil ooze (IA), the Sr-bearing biogenic carbonates, and Ba-bearing siliceous organisms supply the trace elements which are found thereafter with the authigenic minerals, such as clays and zeolites for $\mathrm{Sr}$ and barite for $\mathrm{Ba}$. The occurrence of these elements in biogenic components of pelagic sediments is often cited (El Wakeel and Riley, 1961; Brongersma-Sanders, 1967; Turekian, 1968; Chow and Goldberg, 1970); their release from dissolved biogenic phases and precipitation with secondary minerals has been suggested by Hoffert et al. (1978) and Karpoff (1980). The occurrence of barite and its formation under volcanic influences and (or) in sediments rich in organic material is cited by Goldberg et al. (1969), Boström et al. (1973), Cronan (1974), and Dean and Schreiber (1978). In Site 464 pelagic oozes, the occurrence of barite, and small amounts of zeolites, appears to be a result of a diagenetic evolution under a slight volcanic influence.

The main geochemical characteristic of the brown clay (Unit II) consists in the very low barium content, in the bulk soft sediment and the siliceous slabs or concretions. The cherts from Unit III have the same peculiarity

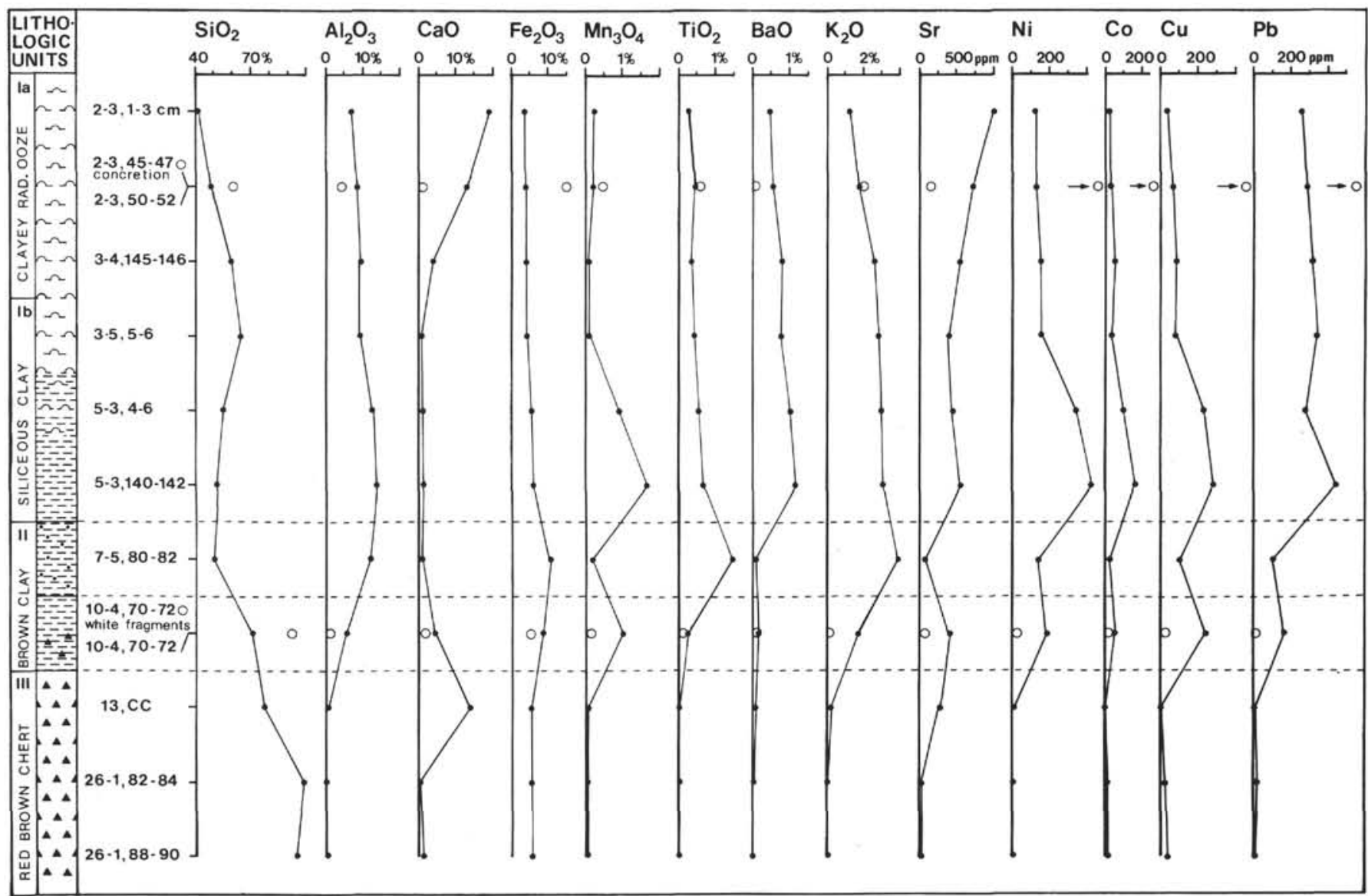

Figure 5. Variations of prevalent elements (oxides in percent, and traces elements in ppm) along the sedimentary column at Site 464 . Thickness of deposits not to scale. Arrows indicate high contents (see Tables 2 and 3 ). 

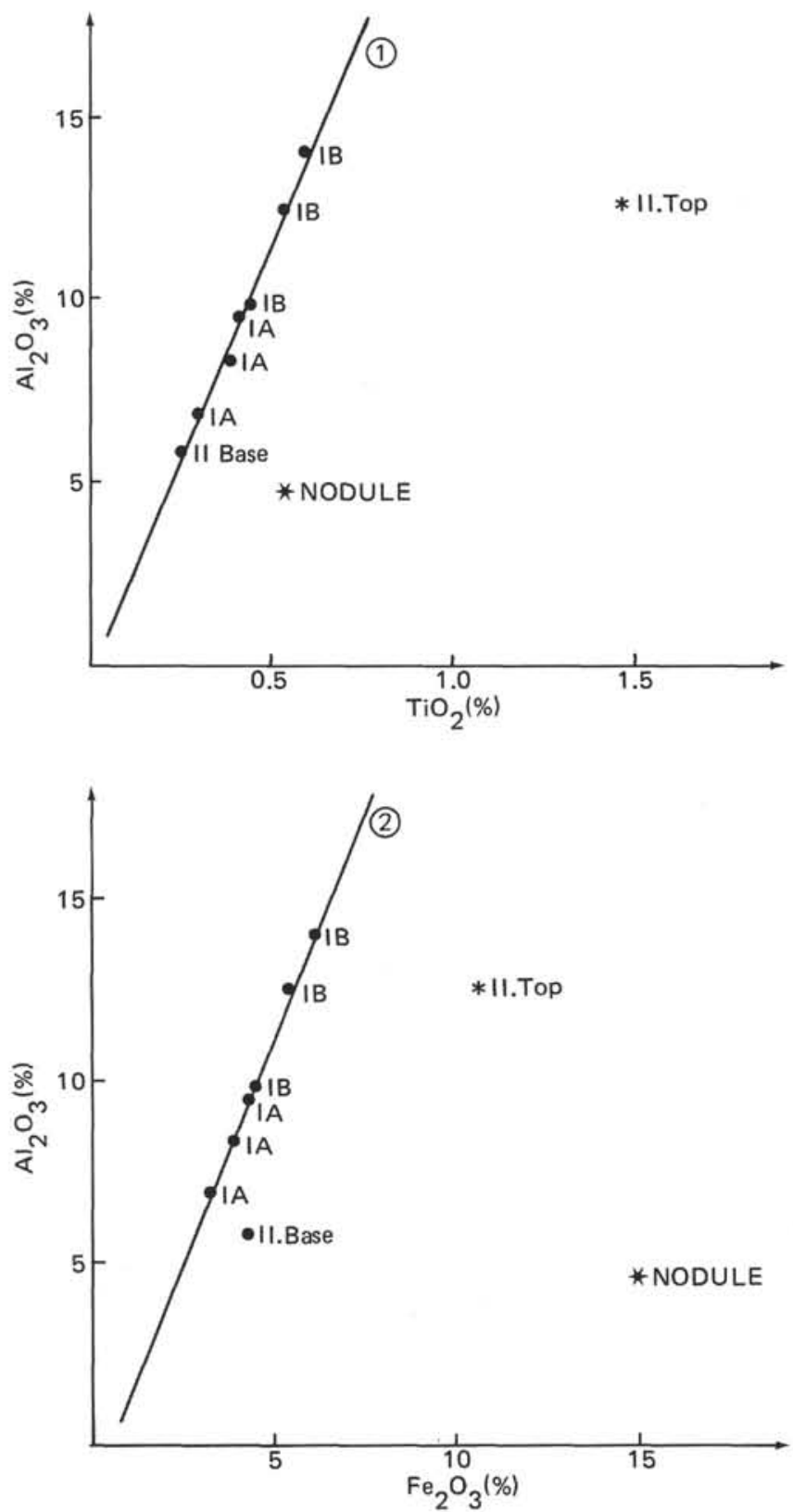

Figure 6. Relationships between $\mathrm{Al}_{2} \mathrm{O}_{3}, \mathrm{TiO}_{2}$, and $\mathrm{Fe}_{2} \mathrm{O}_{3}$ contents of soft sediments of Site 464 (Units IA, IB, and II), and the clayeysiliceous concretion from Unit IA. 1. Regression: $\% \mathrm{Al}_{2} \mathrm{O}_{3}=24.2$ $\% \mathrm{TiO}_{2}-0.53$; correlation coefficient $\mathrm{Al}-\mathrm{Ti}=0.996 .2$. Regression: $\% \mathrm{Al}_{2} \mathrm{O}_{3}=2.47 \% \mathrm{Fe}_{2} \mathrm{O}_{3}-1.03$; correlation coefficient $\mathrm{Al}-\mathrm{Fe}=0.999$

as the coarse siliceous slabs of Unit II: they do not contain any barium. In the soft deposits, the silica released from the dissolved siliceous organisms precipitates and forms quartz-rich concretions, or transforms by epigenesis of calcareous nannofossils (Plate 2, Fig. 1). This secondary silica does not concentrate barium, which is not retained as barite as it is the case in the clayey siliceous ooze (Unit I). The cherts appear to result from the same diagenetic process which is indicated by the Srisotope investigations.

\section{Nickel, Copper and Other Trace Elements}

In the clayey siliceous deposits (Unit IB), the wellknown trace-element assemblage related to clay minerals ( $\mathrm{B}, \mathrm{Ga}, \mathrm{Pb}$, and $\mathrm{V}$ ) cannot easily be discriminated from that of metalliferous oxyhydroxides $(\mathrm{Ni}, \mathrm{Co}, \mathrm{Cu}$, and $\mathrm{Pb}$ ), because of the simultaneously increasing amounts of both phases. Thereby, the relationships of trace elements with detrital clays, authigenic smectite, and oxyhydroxides from the soft sediments were not established. However, bulk and microprobe analyses on the clayey nodule (Unit IA) show that the authigenic $\mathrm{Fe}-\mathrm{Ti}$ beidellites are poor in boron and gallium, preferentially concentrate high contents of $\mathrm{Ni}$, and contain $\mathrm{Co}, \mathrm{Pb}$, and $\mathrm{Zn}$. The scarce $\mathrm{Mn}$-oxides between clay laminae are rich in copper only.

In the second sedimentary unit, trace elements are distributed among clay minerals $(\mathrm{Ga}, \mathrm{Pb}, \mathrm{V})$, volcaniclastic particles ( $\mathrm{V}, \mathrm{Cr})$, micronodules, and ferromanganese oxides $(\mathrm{Ni}, \mathrm{Cu})$. Those oxides from the lower part of the section seem to contain less copper than those of the overlying unit.

Competition between primary minerals, authigenic silicates, and metalliferous oxides to trap the trace elements is confirmed. Particularly, the nickel is trapped in authigenic $\mathrm{Fe}$-smectite when the manganese oxides are scarce, whereas the copper is located in both phases. A volcanic influence probably promoted the formation of such Fe-Ti- and Ni-rich smectites, and their concretionary-nodule structure.

\section{Isotope Analyses: Indications of the Diagenetic Evolution of the Siliceous Horizons \\ METHODS}

$\mathrm{Rb}$ - and $\mathrm{Sr}$-isotope analyses were carried out the siliceous slabs from the bottom of the brown clay, the cherts, and associated limestones (Table 3). The Sr concentrations and isotopic composition on the one hand, and the $\mathrm{Rb}$ concentration on the other hand, were measured on mass spectrometers with $30-$ and $15-\mathrm{cm}$ radii respectively, and corresponding 60 and $90^{\circ}$ deviation angles. The blanks of the complete chemical procedure lie at about $4 \mathrm{ng} / \mathrm{g} \mathrm{Rb}$ and $20 \mathrm{ng} / \mathrm{g} \mathrm{Sr}$ for a 1-g theoretical sample dissolution. The individual error of each ${ }^{87} \mathrm{Sr} /{ }^{86} \mathrm{Sr}$ ratio is given at two standard deviations from the mean. The $\mathrm{Rb} / \mathrm{Sr}$ ratios are estimated as less than $\pm 1 \%$. The results are corrected with the usual constants: ${ }^{85} \mathrm{Rb} /{ }^{87} \mathrm{Rb}=2.591$, and ${ }^{86} \mathrm{Sr} /{ }^{88} \mathrm{Sr}=0.1194$; the ${ }^{87} \mathrm{Sr} /{ }^{86} \mathrm{Sr}$ ratios are also adjusted to 0.71014 for the NBS 987 standard. Further analytical and instrumental conditions are described by Clauer (1976).

\section{Results}

Isotopic ages are calculated assuming that the initial strontium trapped in the siliceous and calcareous material had the same isotopic composition as the sea-water $\mathrm{Sr}$ contemporaneous with the sediments: $0.70743 \pm$ 0.00042 for Albian samples (Dasch and Biscaye, 1971), and $0.70759 \pm 0.00027$ for Late Cretaceous samples (Peterman et al., 1970). For the Cenomanian, no values are available; therefore, we used the Albian value. The isotopic ages are systematically older than biostratigraphic data (Table 4). This discrepancy can be explained by an alteration of minerals, as well as by exchanges with the interstitial environment, which could 
Table 4. $\mathrm{Rb} / \mathrm{Sr}$ isotopic data on siliceous, calcareous, and bulk material from the "red clays" and cherts from Site 464.

\begin{tabular}{|c|c|c|c|c|c|c|}
\hline Sample & $\begin{array}{c}\text { Biostratigraphic } \\
\text { Age }\end{array}$ & $\underset{(\mu \mathrm{g} / \mathrm{g})}{\mathrm{Rb}}$ & $\underset{(\mu g / g)}{\mathrm{Sr}}$ & ${ }^{87} \mathrm{Rb} /{ }^{86} \mathrm{Sr}$ & ${ }^{87} \mathrm{Sr} /{ }^{86} \mathrm{Sr}{ }^{*}$ & $\begin{array}{l}\text { Isotopic } \\
\text { Age }\end{array}$ \\
\hline $464-10-4,70-72 \mathrm{~cm}$ & $\begin{array}{l}\text { Late Cretaceous: } \\
80 \pm 20 \text { m.y. }\end{array}$ & 4.22 & 25.7 & 0.476 & $0.70903 \pm 21$ & $215 \pm 90 \mathrm{~m} . \mathrm{y}$. \\
\hline $\begin{array}{l}\text { 464-13,CC, bulk chert } \\
464-13, \text { CC, calcite } \\
464-13, \text { CC, silica (chert) } \\
464-13, \text { CC, silica (other chert) }\end{array}$ & $\begin{array}{l}\text { Cenomanian: } \\
98 \pm 2 \text { m.y. }\end{array}$ & $\begin{array}{l}9.37 \\
-\overline{12.7} \\
4.82\end{array}$ & $\begin{array}{l}248 \\
796 \\
4.53 \\
6.49\end{array}$ & $\begin{array}{l}0.109 \\
-\overline{100} \\
2.152\end{array}$ & $\left.\begin{array}{l}0.70756 \pm 10 \\
0.70769 \pm 27 \\
0.73489 \pm 29 \\
0.71505 \pm 18\end{array}\right\}$ & $\begin{array}{l}240 \pm 10 \mathrm{~m} . \mathrm{y} . \\
250 \pm 30 \mathrm{~m} . \mathrm{y} .\end{array}$ \\
\hline $\begin{array}{l}464-26-1,82-84 \mathrm{~cm} \text {, chert } \\
464-26-1,88-90 \mathrm{~cm} \text {, bulk } \\
464-26-1,88-90 \mathrm{~cm} \text {, calcite } \\
464-26-1,88-90 \mathrm{~cm} \text {, silica }\end{array}$ & $\begin{array}{l}\text { Albian: } \\
100 \pm 6 \text { m.y. }\end{array}$ & $\begin{array}{l}0.72 \\
0.80 \\
- \\
1.32\end{array}$ & $\begin{array}{c}6.99 \\
19.7 \\
511 \\
1.40\end{array}$ & $\begin{array}{c}0.296 \\
0.118 \\
\overline{2.732}\end{array}$ & $\left.\begin{array}{l}0.70977 \pm 22 \\
0.70779 \pm 21 \\
0.70765 \pm 11 \\
0.71188 \pm 65\end{array}\right\}$ & $\begin{array}{l}555 \pm 90 \mathrm{~m} . \mathrm{y} . \\
115 \pm 20 \mathrm{~m} . \mathrm{y} .\end{array}$ \\
\hline
\end{tabular}

- The ${ }^{87} \mathrm{Sr} / 86 \mathrm{Sr}$ ratios were corrected for a ${ }^{86} \mathrm{Sr} / 88 \mathrm{Sr}$ ratio at 0.1194 and adjusted to 0.71014 for the NBS 987 standard. The individual error of each run $(2 \sigma / \sqrt{\mathrm{N}})$ is given in $10^{-5}$. Ages are calculated with the new decay constant $\lambda^{87} \mathrm{Rb}=1.42 \times 10^{-11} \times a^{-1}$.

be enriched in ${ }^{87} \mathrm{Sr}$, as was already observed on the case of interstitial waters from "red clays"' (Clauer et al., 1975). The initial $\mathrm{Sr}$ amounts of siliceous material are very low, (1.4-7 $\mathrm{ng} / \mathrm{g})$, smaller than those of present day sea water. A slight "contamination"' from the surrounding environment therefore can explain the discrepancies in the ages. Thus, the siliceous compounds evolved by diagenesis in an open system since the dissolution of the biogenic silica, until chert and aggregate formation by recrystallization. On the other hand, the calcite associated with cherts shows ${ }^{87} \mathrm{Sr} /{ }^{86} \mathrm{Sr}$ ratios close those of the contemporaneous of deposits sea water, respectively $+22 \times 10^{-5}$ for the Albian sample and $+10 \times 10^{-5}$ for the Cenomanian sample (Table 4). The calcite certainly has also evolved in an open system during the chert formation, but "contamination" is negligible because of the high initial $\mathrm{Sr}$ contents $(>500$ $\mu \mathrm{g} / \mathrm{g})$.

These results confirm those from a previous study on siliceous rocks from central Pacific deposits (Karpoff, 1977). They also emphasize the difficulties encountered when dating siliceous material, considered by Brueckner and Snyder (1979), whereas the ${ }^{87} \mathrm{Sr} /{ }^{86} \mathrm{Sr}$ ratios of the little-transformed calcareous residual inclusions in cherts can be used for dating these formations.

\section{DISCUSSION: INFLUENCE OF THE SEDIMENTATION ENVIRONMENT ON SILICATES AND SILICA AUTHIGENESIS}

\section{Authigenic Clays}

Analytical data indicate that several types of clay authigenesis are represented in the sedimentary column. Nevertheless, results were not sufficient to point to the causes of the segregation and differentiation of authigenic smectites forming concretions in a siliceous ooze, which also contains another clay-mineral assemblage. However, the ferroan and titaniferous nature of the nodule smectites is similar to that of authigenic smectites formed in a submarine environment with strong volcanic influences, particularly where nontronites and Fe-Mn crusts are found, Sites 430 and 431 (Fig. 1) (Karpoff et al., 1980). Therefore, a local volcanic influence seems to have acted upon Pliocene clayey-siliceous oozes, and helped the formation of $\mathrm{Fe}$-Ti-smectites distinct from those resulting from the dissolution of organisms. This volcanic influence was certainly very slight; it favored zeolite and barite formation, and did not end with $\mathrm{Fe}-\mathrm{Mn}$-oxide precipitation.

In the brown clay, smectites are essentially authigenic and result from the dissolution of siliceous organisms. Glasses and volcaniclastic particles are the only traces of a volcanogenic contribution, which helps however the formation of $\mathrm{Fe}-\mathrm{Mn}$ oxides and micronodules, and small amounts of zeolites. Palygorskite-type particles form the clay fraction, related to the hypersilicic nature of the deposits and the presence of quartz aggregates. Authigenic palygorskite in siliceous sediments is frequently encountered in alkaline environments (Isphoding, 1973; Donnely and Merrill, 1977). These clays have also been ascribed to weathering of volcanic material or transformation of smectites (Hathaway and Sachs, 1965; Bonatti and Joenssu, 1968; Lancelot, 1973; Couture, 1977). Small amounts of palygorskite encountered in brown oozes from Site 464 result from the hypersilicic environment. This authigenesis follows those which are related to the dissolution of organisms.

\section{Silica Authigenesis}

Cristobalite from bentonites, shales, and cherts is often ascribed to authigenesis related to dissolution of biogenic opal, volcanic glass, and sometimes quartz (Peterson and von der Borch, 1965; Wise et al., 1972; Wise and Weaver, 1974; Klasik, 1975; Wilding et al., 1977). Cristobalite is sometimes described as the precursor of quartz in the $\mathrm{SiO}_{2}$ evolutionary maturation sequence which starts with biogenic opal or amorphous silica (Ernst and Calvert, 1969; Mitzutani, 1970). The possibility of a mixed volcanogenic-biogenic origin of the cherts has been suspected (Gibson and Towe, 1971; Castellarini and Sartori, 1978). Kastner et al. (1977) established the following diagenetic succession: siliceous ooze (opal-A) $\rightarrow$ porcellanite (opal-CT) $\rightarrow$ chert (chalcedony, cryptocrystalline quartz). These authors reviewed the common hypotheses for silica diagenesis. According to Wiley (1978), the ratio between clays and biogenic-silica amounts affects silica dissolution. Similarly, von Rad (1979), after discussing authigenic and diagenetic processes of $\mathrm{SiO}_{2}$ evolution through time, suggests that opal-CT formation is faster in carbonate than clayey sediments, and that the clayey environment slows the transformation of opal-CT into quartz. 
Greenwood (1973), Lancelot (1973), and Kastner et al., (1977) show that cherts are cristobalite in clayey horizons, whereas quartz is most common in carbonate sediments. The possibility of quartz precipitation during an early stage of porcellanite diagenesis or epigenesis of organisms is also suggested by von Rad (1979).

In Site 464 brown clay, authigenic quartz with small amounts of cristobalite is common, whereas cherts are essentially cristobalite. Evidence supporting the diagenetic formation of Albian-Cenomanian cherts agrees with studies by Kastner et al. (1977), Riech and von Rad (1979), and von Rad (1979).

On the other hand, the occurrence of authigenic quartz in deep-sea sediments, particularly in siliceous ooze and manganese-crust-bearing volcanic sedimentary deposits, has already been described (Karpoff, 1977; Hoffert et al., 1978). Therefore, authigenic microcrystalline quartz in the clayey nodule from Unit IA appears to have formed along with the concretion of iron smectite in siliceous pelagic deposits under a slight volcanic influence; this is seen to be a stage of silica evolution in this marine environment.

However, in brown clay from Site 464 quartz-concretion crystallization and epigenesis are due to diagenetic processes similar to those of chert formation. It results from dissolution of biogenic silica and is strongly affected by clay- and oxyhydroxide-rich environments. Quartz-concretion authigenesis cannot be considered the result of restricted and local phenomena because of their abundance. They are an essential stage of brown or red clay evolution through time. Thus, differences between the two siliceous phases, concretions and cherts, from Site 464-such as their age, the deposition depths, and the carbonate, clay, and Fe-Mn-oxide contentshave controlled the diagenetic evolution of silica. The importance of these factors in chert formation has already been mentioned by Lancelot (1973), Keene (1975), and Kastner et al. (1977).

\section{CONCLUSIONS}

The lithologic sequence at Site 464 appears to be a result of interaction of three connected evolutionary factors:

1) The biogenic components, as calcareous nannofossils and siliceous organisms, form the upper deposits, and their dissolution and a slight volcanic influence promote the authigenesis of clays, zeolites, and barite.

2) The clay assemblages, as detrital clays and authigenic smectites, vary with the sequence. From the dissolution of siliceous organisms, the smectites are distinct ringlet-shaped particles, or laths, in the upper siliceous ooze and clay and in the brown clays, respectively. Under a volcanic influence, authigenic $\mathrm{Fe}$-smectites are formed which are chemically distinct from those of the soft host pelagic sediments. Authigenic palygorskite occurs on brown clay characterized by a hypersiliceous environment.

3) The silica cycle and evolution induce the authigenic formation of microcrystalline quartz associated with clayey nodules in the siliceous ooze. In the brown clay, the quartz-rich concretions and aggregates appear to be derived from the same diagenetic process as the chert, but probably influenced by a previous calcareous environment.

These factors have conditioned the mineralogical and chemical characteristics of the brown clay. Therefore, the lower part of this unit, of Cretaceous age (Doyle and Riedel, this volume), and the Paleocene upper part, appear to be similar to the "red clay" facies, formed respectively from calcareous biogenic ooze and from siliceous biogenic ooze, as described by Hoffert (1980).

The intermittent volcanic influence during deposition of the Site 464 sediments was more marked during the Paleocene-Eocene and Miocene-Pliocene, and is in accordance with that suggested by the studies of sediments from Sites 310 and 433 .

Nevertheless, the marine environment-location, depth of deposition, geologic history, and hiatuses-induces varying lithologic sequences in these sites, correspondingly more calcareous pelagic deposits at Hess Rise (Site 310), and more volcanogenic sediments on the Emperor Seamounts (Sites 430, 433), compared to the pelagic sediments at Site 464 .

\section{ACKNOWLEDGMENTS}

The analytical work was performed with the technical support of the Centre de Sédimentologie et Géochimie de la Surface of the C.N.R.S. and of the Institut de Géologie, Strasbourg, especially D. Trauth, I. Zimmerlin, B. Kiefel, R. A. Wendling, and R. Winkler. The authors are grateful to José Honnorez for helpful criticism, and to Yves Lancelot and Michel Steinberg for suggestions.

\section{REFERENCES}

Besnus, Y., and Lucas, J., 1968. Méthode de dosage de 18 éléments majeurs et traces dans les roches sédimentaires et les produits d'altération, par spectromètrie à lecture directe. Coll. Nat., C.N.R.S., 923:93-106.

Besnus, Y., and Rouault, R., 1973. Une méthode d'analyse des roches au spectromètre d'arc à lecture directe par un dispositif d'électrode rotative. Analusis, 2:111-116.

Bonatti, E., and Joenssu, O., 1968. Palygorskite from Atlantic deep sea sediments. Am. Mineral., 53:975-983.

Boström, K., Joenssu, O., Moore, C., et al., 1973. Geochemistry of barium in pelagic sediments. Lithos, 6:159-174.

Brongersma-Sanders, M., 1967. Barium in pelagic sediments and diatoms. K.K.L. Nederl. Akad. Wetersh. Proc., B:93-99.

Brueckner, H. K., and Snyder, W. S., 1979. Rb-Sr dating of chert: a potential chronological tool. Geol. Soc. Am. Abs. Prog., 11-2:71.

Castellarini, A., and Sartori, R., 1978. Quaternary iron-manganese deposits and associated pelagic sediments (radiolarian clay and cherts, gypsiferous mud) from the Thyrrhenian Sea. Sedimentol., 25:801-821.

Chow, T. J., and Goldberg, E. D., 1970. On the marine geochemistry of barium. Geochim. Cosmochim. Acta, 20:192-198.

Clauer, N., 1976. Géochimie isotopique du strontium des milieux sédimentaires. Application à la géochronologie de la couverture du Craton Ouest-Africain. Mém. Sci. Géol. Strasbourg, 45:256.

Clauer, N., Hoffert, M., Grimaud, D., et al., 1975. Composition isotopique du strontium d'eaux interstitielles extraites de sédiments récents: un argument en faveur de l'homogénéisation isotopique des minéraux argileux. Geochim. Cosmochim. Acta, 39:15791582.

Couture, R. A., 1977. Composition and origin of palygorskite-rich and montmorillonite-rich zeolite containing sediments from the Pacific Ocean. Chem. Geol., 19:113-130.

Cronan, D. S., 1974. Authigenic minerals in deep sea sediments. In Hill, M. N. (Ed.), The Sea (Vol. 5): New York (Interscience), 491-525.

Dasch, E. J., and Biscaye, P. E., 1971. Isotopic composition of strontium in Cretaceous to recent pelagic foraminifera. Earth Planet. Sci. Lett., 11:201-204. 
Dean, W. E. and Schreiber, B. C., 1978. Authigenic barite, Leg 41. In Lancelot, Y., Seibold, E., et al. Init. Repts. DSDP, 41: Washington (U.S. Govt. Printing Office), 915-931.

Donnely, T. W., and Merrill, I., 1977. The scavenging of magnesium and other chemical species by biogenic opal in deep sea sediments. Chem. Geol., 19:167-186.

El Wakeel, S. K., and Riley, J. P., 1961. Chemical and mineralogical studies of deep sea sediments. Geochim. Cosmochim. Acta, 25: $110-146$.

Ernst, W. G., and Calvert, S. E., 1969. An experimental study of the recrystallization of porcelanite and its bearing on the origin of some bedded cherts. Am. J. Sci., 267A:114-133.

Gibson, T. G., and Towe, K. M., 1971. Eocene volcanism and the origin of horizon A. Science, 172:152-154.

Goldberg, E. D., Somayajulu, B. L. K., and Galloway, J., 1969. Differences between barites of marine and continental origins. Geochim. Cosmochim. Acta, 33:287-289.

Greenwood, R., 1973. Cristobalite: its relationship to chert formation in selected samples from the Deep Sea Drilling Project. J. Sediment. Petrol., 43:700-708.

Hathaway, J., and Sachs, P., 1965. Sepiolite and clinoptilolite from the Mid-Atlantic Ridge. Am. Mineral., 50:852-867.

Hoffert, M., 1980. Les "argiles rouges"' des grands fonds dans le Pacifique Centre-Est. Thèse Doc. ès Sci., et Mém. Sci. Géol., Strasbourg, 61:231.

Hoffert, M., Karpoff, A. M., Clauer, N., et al., 1978. Néoformation et altération dans trois faciès volcanosédimentaires du Pacifique Sud. Oceanol. Acta, 1-1:187-202.

Isphoding, W. C., 1973. Discussion of the occurrence and origin of sedimentary palygorskite-sepiolite deposits. Clays Clay Min., 21:391-401.

Karpoff, A. M., 1977. Plättchenformiges Silizium mit polymetallischen Konkretionen vergesellschafted aus den rezenten Sedimenten des Nördlichen Pazific. Ergebnisse der ManganknollenWissenschaftfahrt VA 13/2. Zentraler Pazifischer Ocean. Hannover (B.G.R.), p. 1.

1980. The sedimentary deposits of Suiko Seamount (Leg 55, Site 433): from the reef environment to pelagic sedimentation. In Jackson, E. D., Koizumi, I., et al., Init. Repts. DSDP, 55: Washington (U.S. Govt. Printing Office), 491-502.

Karpoff, A. M., Peterschmitt, I., and Hoffert, M., 1980. Mineralogy and geochemistry of sedimentary deposits on Emperor Seamounts, Sites $430,431,432$ : authigenesis of silicates, phosphates and ferromanganese oxides. In Jackson, E. D., Koizumi, I., et al., Init. Repts. DSDP, 55: Washington (U.S. Govt. Printing Office), 463-490.

Kastner, M., Keene, J. B., and Gieskes, J. M., 1977. Diagenesis of siliceous ooze-I. Chemical controls on the rates of
opal-A to opal-CT transformation, an experimental study. Geochim. Cosmochim. Acta, 41:1041-1059.

Keene, J. B., 1975. Cherts and porcelanites from the North Pacific, DSDP Leg 32. In Larson, R. L., Moberly, R., et al., Init. Repts. $D S D P, 32$ : Washington (U.S. Govt. Printing Office), 429-448.

Klasik, J. A., 1975. High cristobalite and high tridymite in a middle eocene deep sea chert. Science, 189:631-632.

Lancelot, Y., 1973. Chert and silica diagenesis in sediments from the Central Pacific. In Winterer, E. L., Ewing, J. I. et al., Init. Repts. DSDP, 17: Washington (U.S. Govt. Printing Office), 337-405.

Millot, G., 1949. Relation entre la constitution et la genèse des roches sédimentaires argileuses. Géol. Appl. Prosp. Min., 2:1-352.

Mise au point collective, 1975. Technique de préparation des minéraux argileux en vue de l'analyse par diffraction des Rayons X. Notes Techniques de l'Institut de Géologie, No. 1: Strasbourg (U.L.P.).

Mitzutani, S., 1970. Silica minerals in early stage of diagenesis. Sedimentol., 15:419-436.

Peterman, Z. E., Hedge, C. E., and Tourtelot, H. A., 1970. Isotopic composition on seawater throughout Phanerozoic time. Geochim. Cosmochim. Acta, 34:105-120.

Peterson, M. N. A., and von der Borch, C. C., 1965. Chert-modern inorganic deposition in a carbonate-precipitating locality. Science, 149:1501-1503.

Riech, V., and von Rad, U., 1979. Eocene porcelanites and early cretaceous cherts from the Western North Atlantic. In Tucholke, B., Vogt, P. R., et al., Init. Repts. DSDP, 43: Washington (U.S. Govt. Printing Office), 437-455.

Sorem, R. K., and Fewkes, R. H., 1977. Internal characteristics. In Glasby, G. P. (Ed.), Marine Manganese Deposits: New York (Elsevier), pp. 147-184.

Trauth, D., Ehret G., Eberhart, J. P., et al., 1977. Microscopie électronique et minéraux argileux: resultats obtenus et orientations actuelles. Notes Tech. Inst. Geol., 7:16.

Turekian, K. K., 1968. Deep sea deposition of barium, cobalt and silver. Geochim. Cosmochim. Acta, 32:603-612.

von Rad, U., 1979. $\mathrm{SiO}_{2}-$ Diagenese in Tiefseesedimenten. Geol. Rundsch., 68:1025-1036.

Wilding, L. P., Smeck, N. E., and Drees, L. R., 1977. Silica in soils: quartz, cristobalite, tridymite and opal. In Dixon, J. B., and Weed, S. B. (Eds.), Minerals in Soils Environments: Madison (Soil Sci. Soc. Am.), pp. 471-552.

Wiley, J. D., 1978. Release and uptake of dissolved silica in seawater by marine sediments. Mar. Chem., 7:53-65.

Wise, S. W., Jr., Buie, F. B., and Weaver, F. M., 1972. Chemically precipitated sedimentary cristobalite and origin of cherts. Eclogae Geol. Helv., 65:157-163.

Wise, S. W., Jr. and Weaver, F. M., 1974. Chertification of ocean sediments. Int. Assoc. Sedimentol. Spec. Pub., 1:301-326. 

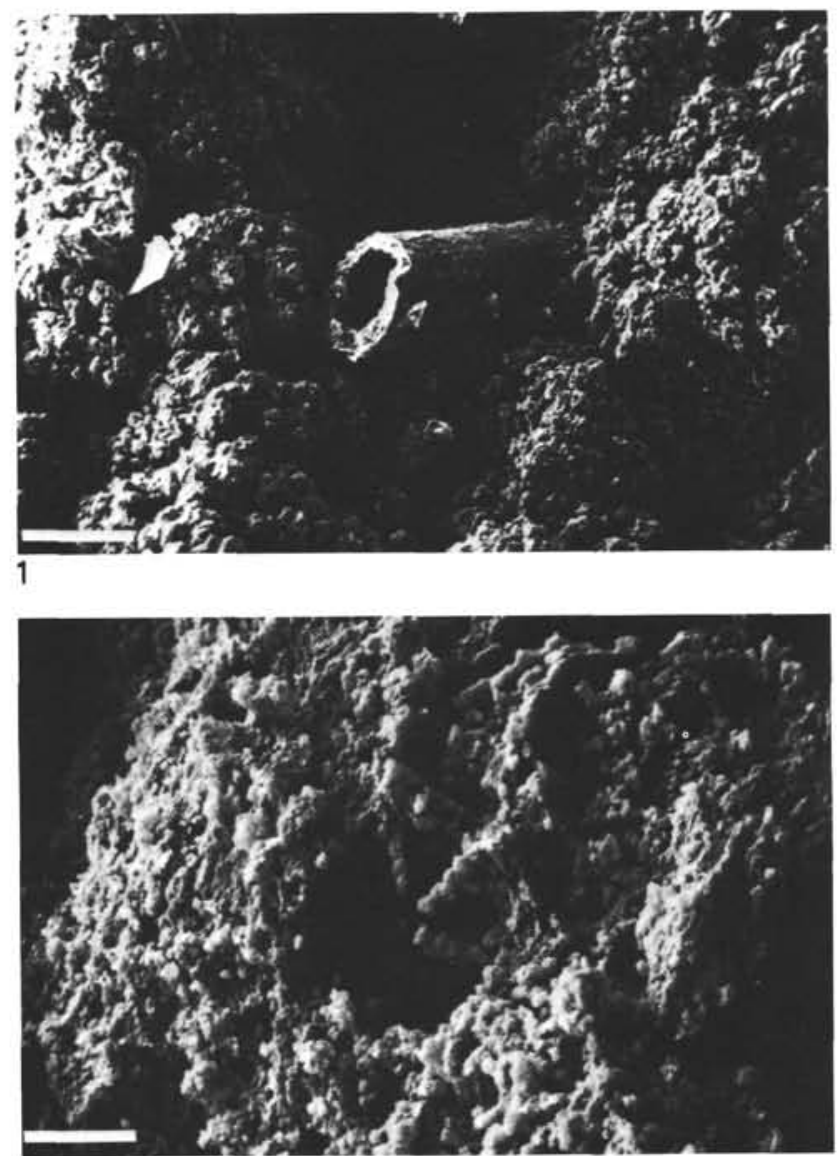

3

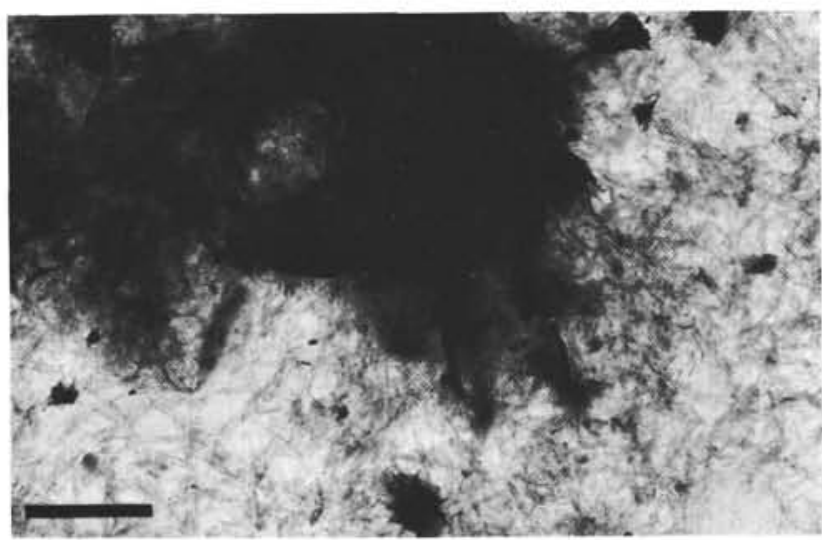

5

Plate 1. SEM photomicrographs of the bulk sediment (Figs. 1 to 4 ) and TEM photomicrographs of the clay fraction (Figs. 5 and 6 ) of the brown clay from the top of Unit II, Sample 464-7-5, 80-82 cm.

Figure 1. General view of the sediment with a sponge spicule; scale bar $50 \mu \mathrm{m}$.

Figure 2. High magnification of Figure 1, showing the inner cavity of sponge spicule with authigenic crystals of zeolite; scale bar $5 \mu \mathrm{m}$.

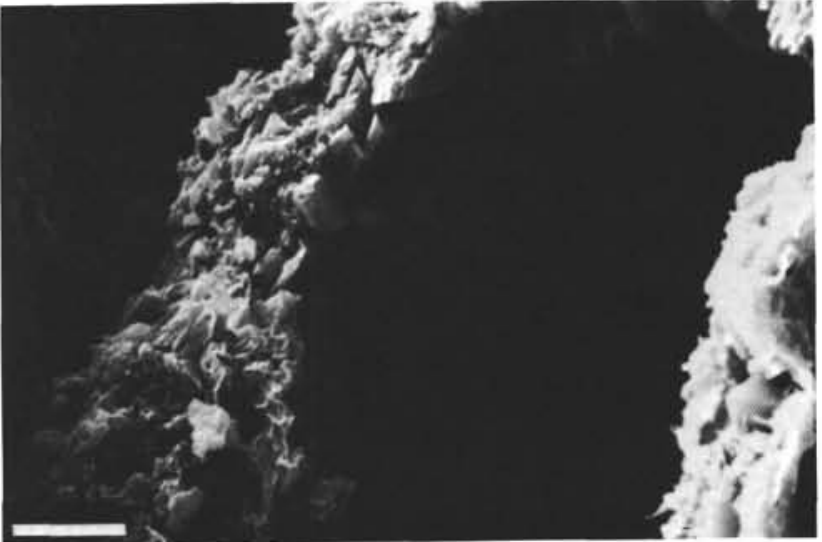

2

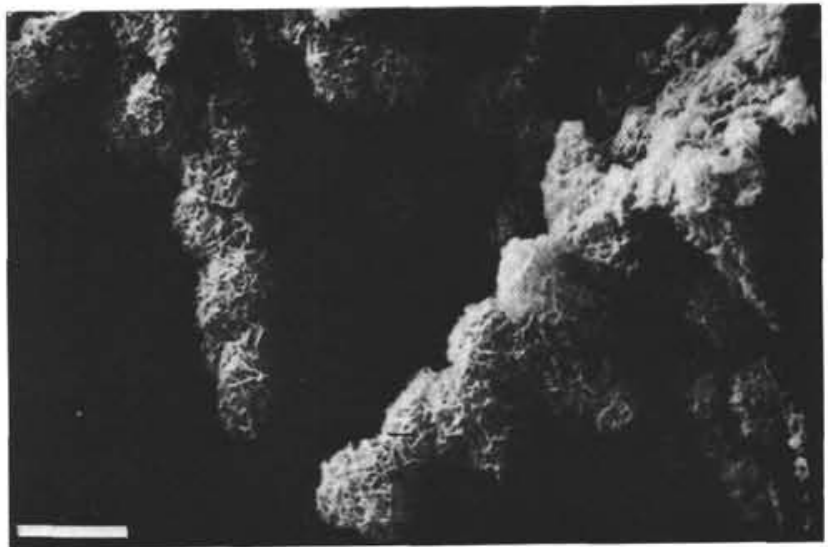

4

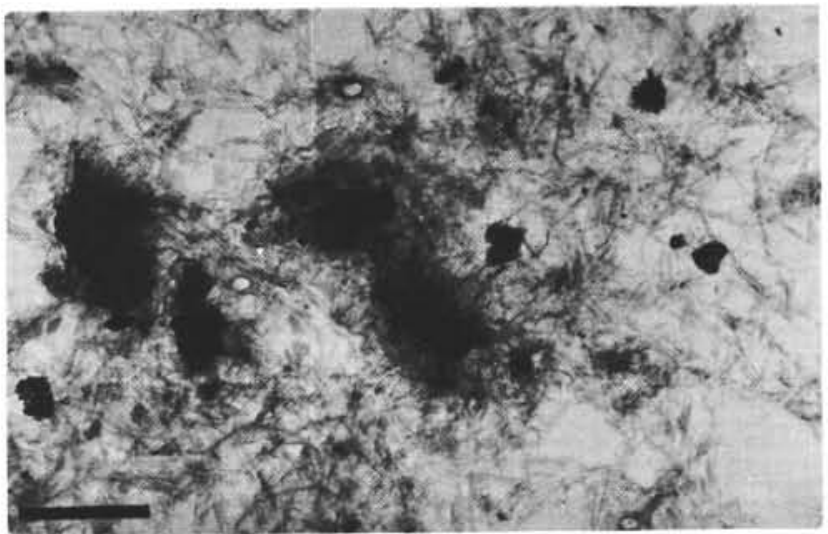

6

Figure 3. Beginning formation of a micronodule in the brown clay; scale bar $50 \mu \mathrm{m}$.

Figure 4. High magnification of Figure 3; crystallization of manganese oxide mixed with clays; scale bar $10 \mu \mathrm{m}$.

Figure 5. Clay fraction with big particle of smectite fringed by fine fibers; scale bar $2 \mu \mathrm{m}$.

Figure 6. General view of the clay fraction of authigenic smectites (particles and fibers); scale bar $2 \mu \mathrm{m}$. 


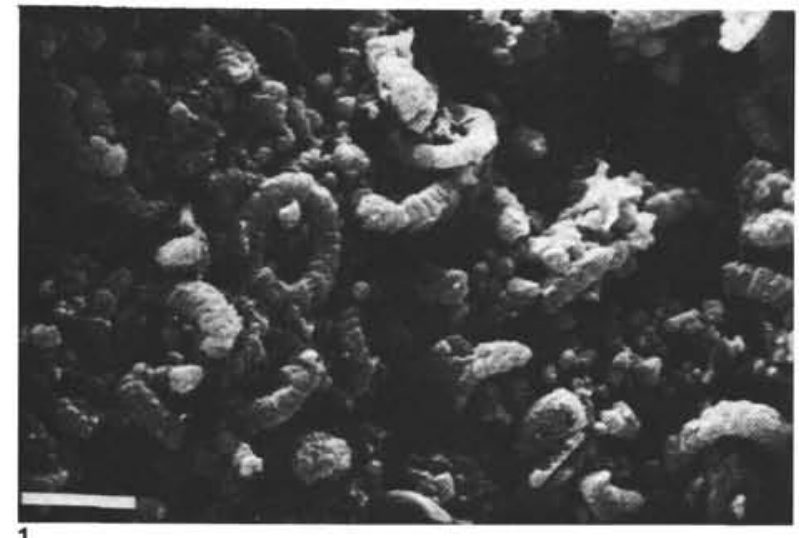

1

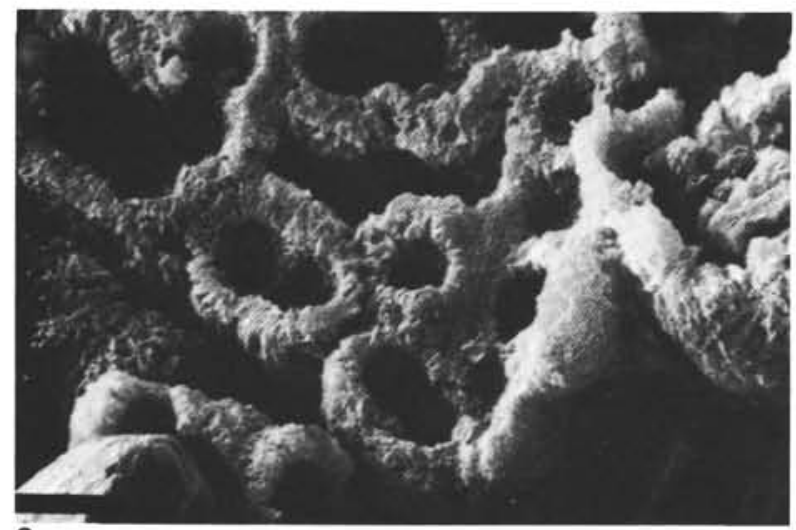

3

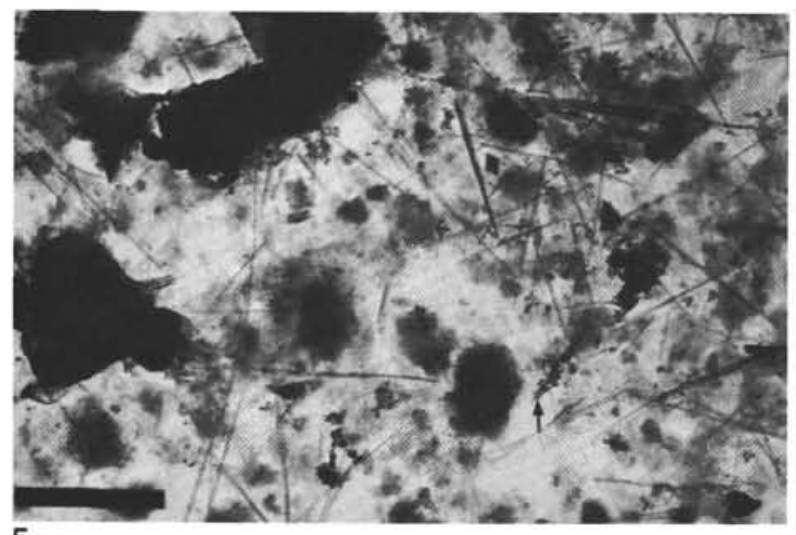

5

Plate 2. SEM photomicrographs of the white slabs of the coarse fraction (Figs. 1 to 4 ) and TEM photomicrographs of the clay fraction (Figs. 5 and 6) of the brown clay from the base of Unit II, Sample $464-10-4,70-72 \mathrm{~cm}$.

Figure 1. White fragment composed of silicified coccoliths; scale bar 5 $\mu \mathrm{m}$.

Figure 2. White slabs composed of siliceous "lepispheres" and coated crystals of zeolite (Z); scale bar $20 \mu \mathrm{m}$.
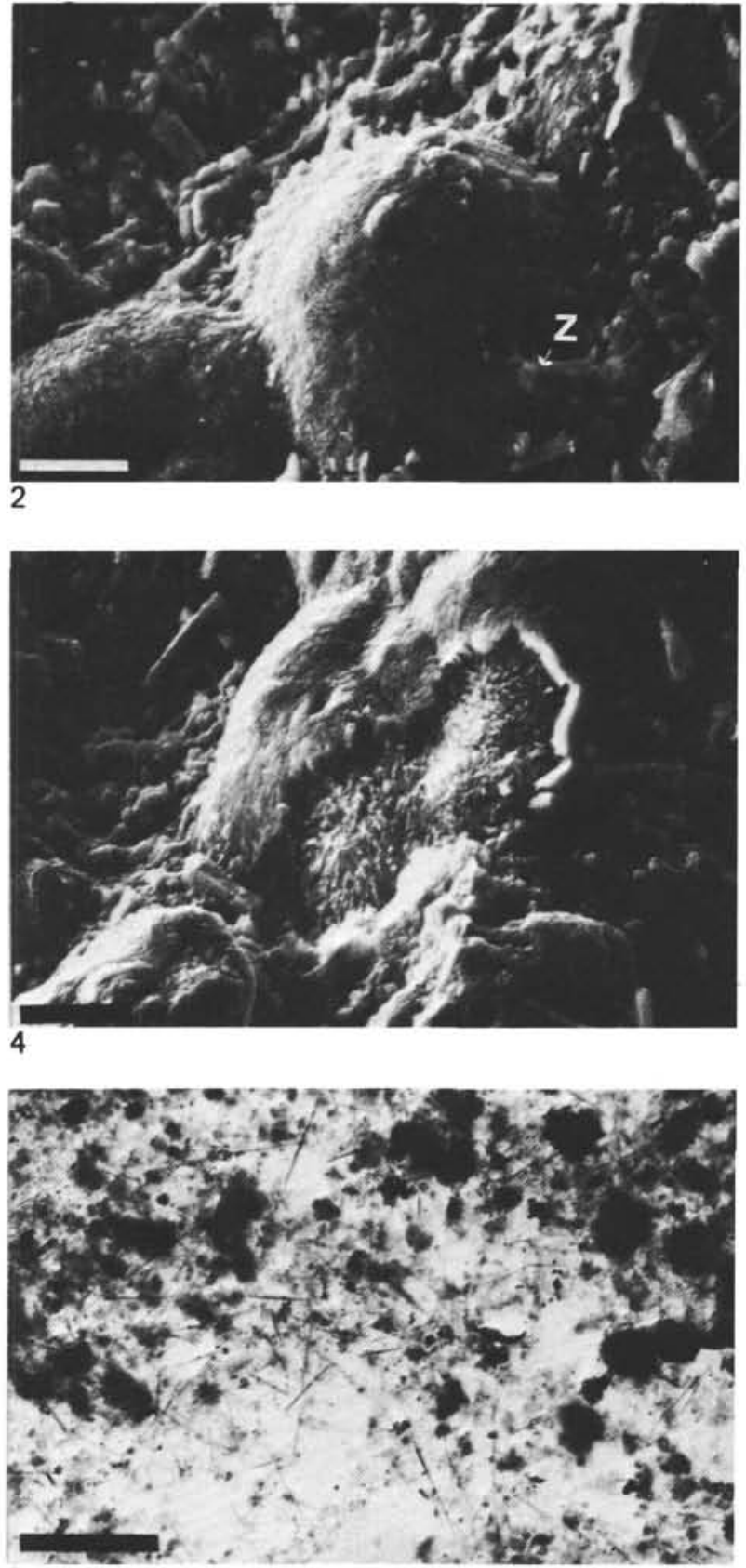

6

Figure 3. Detail of a siliceous slab with residual radiolarian; scale bar $10 \mu \mathrm{m}$.

Figure 4. Detail of the siliceous "lepispheres" with successive laminae of silica; scale bar $20 \mu \mathrm{m}$.

Figure 5. Clay fraction containing smectite particles and palygorskite laths; very small globules of silica occur $(\rightarrow)$; scale bar $2 \mu \mathrm{m}$.

Figure 6. General view of the clay fraction; the smectites prevail; scale bar $4 \mu \mathrm{m}$. 


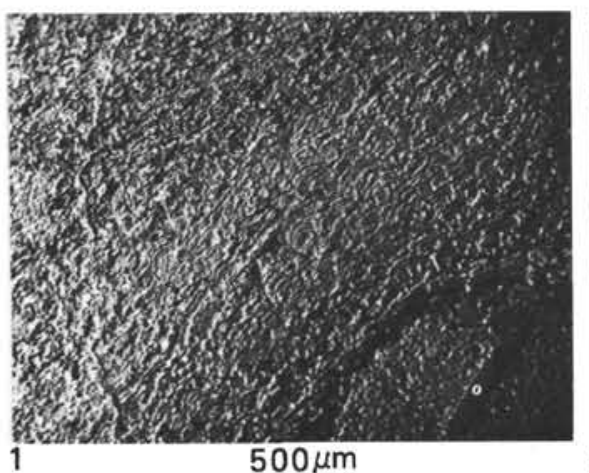

$500 \mu \mathrm{m}$

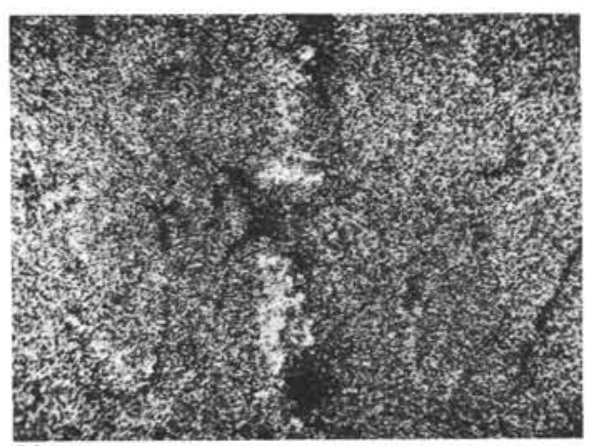

$\mathrm{Si}$

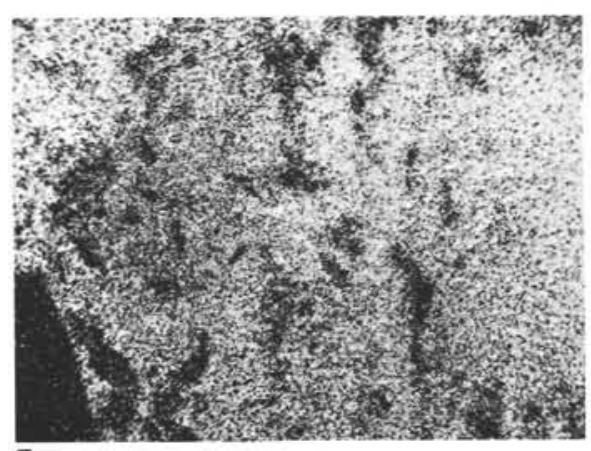

$\mathrm{Fe}$

Plate 3. SEM chemical studies on polished section of the clayeysiliceous concretion from the sedimentary deposits of Unit IA, Sample 464-2-3, $45-47 \mathrm{~cm}$.

Figure 1. General view of the polished section. Contact between the nodule core and a feldspar crystal and the successive layers of clays forming the cortex; the square shows the location of the analyzed area.

Al
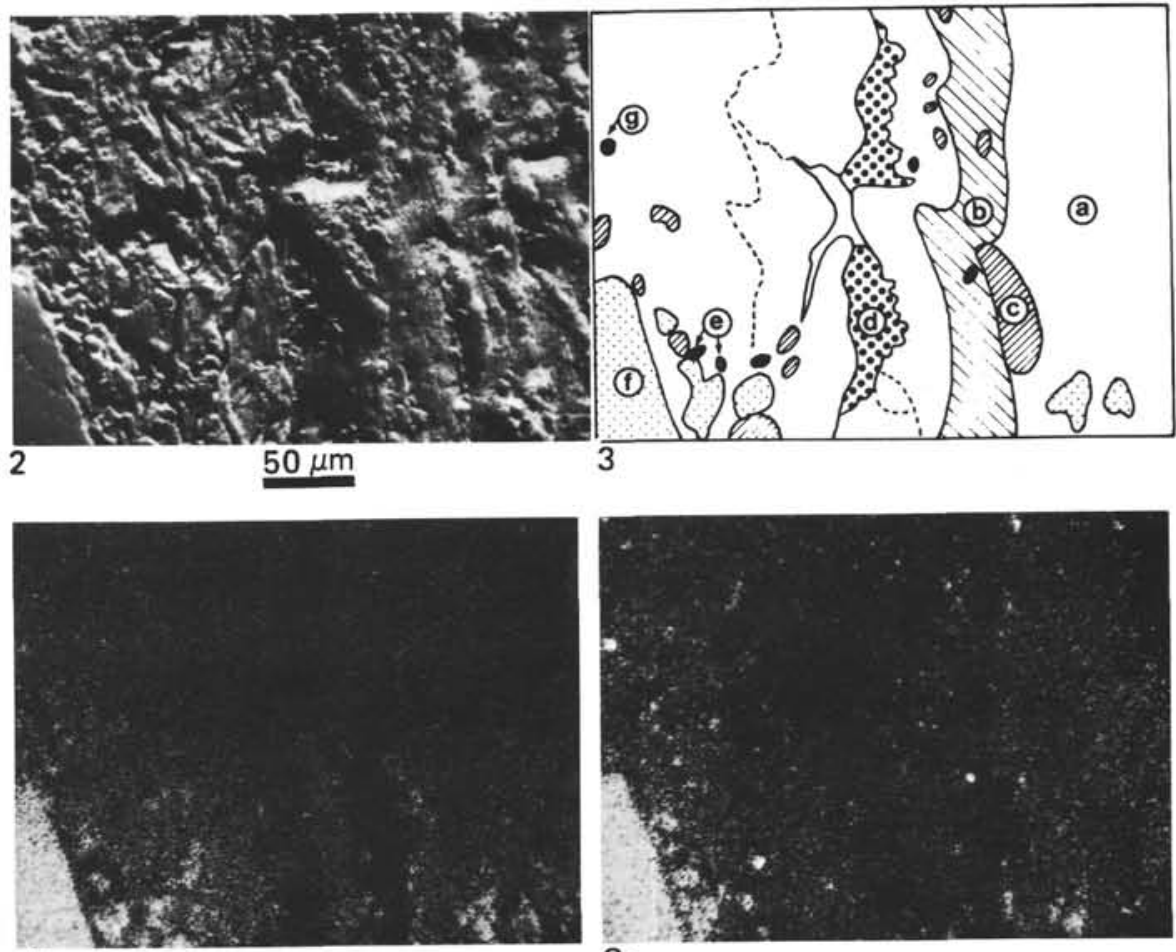

$\mathrm{Ca}$
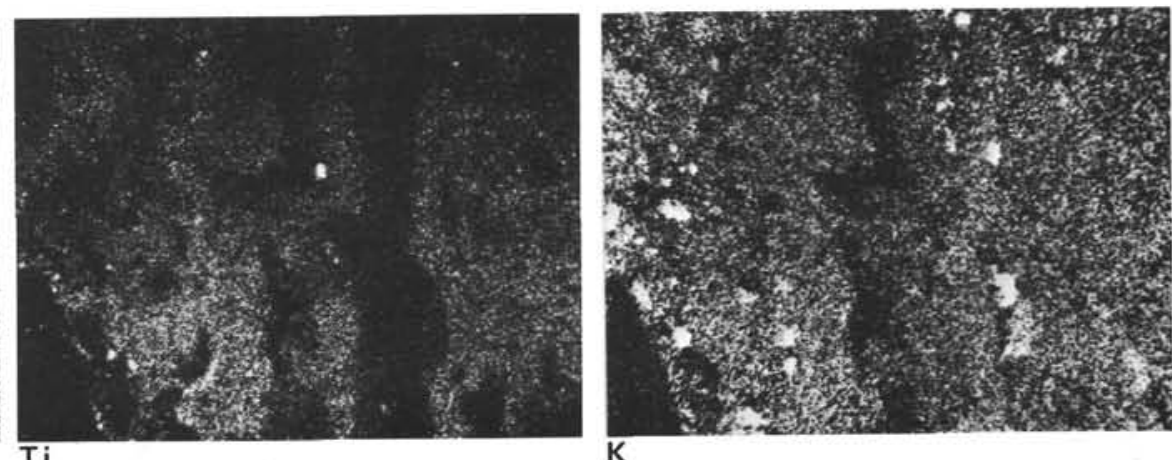

Figure 2. SEM microphotograph of the analyzed area, with the equivalent maps of $\mathrm{Si}, \mathrm{Al}, \mathrm{Ca}, \mathrm{Fe}, \mathrm{Ti}$, and $\mathrm{K}$ contents.

Figure 3 . Schematic drawing of the various components. a. Prevalent $\mathrm{Fe}$-Ti-rich clays, b. Fe-clay layer without $\mathrm{Ti}$. c. Interlayered $\mathrm{K}$-silicates as zeolite. d. Layer of fine crystals of quartz. e. Fe-Ti oxides. f. Feldspar crystal. g. Micropatches of carbonate as calcareous microfossils. 